\title{
PENINGKATAN AKTIVITAS PENDIDIKAN KEBERAGAMAAN ISTRI PEGAWAI NEGERI SIPIL MELALUI ARISAN PADA KEGIATAN RUTINITAS BULANAN DI DHARMA WANITA PERSATUAN IAIN PADANGSIDIMPUAN
}

\author{
Hj. ASFIATI \\ Dosen Fakultas Tarbiyah dan Ilmu Keguruan IAIN Padangsidimpuan \\ Email: asfiati_hasibuan@yahoo.co.id
}

\begin{abstract}
The results of the study found that the monthly recitation is one program that explores religious activities in order to improve religious education of the members of Dharma Wanita Persatuan of State Institute for Islamic Studies (IAIN) Padangsidimpuan. The constraints found perception about the timing and schedule of activities for each of members has its own flurry of activity which also supports other activities as the wife of civil servants and as a civil servant. Other constraints due to the heterogeneous nature of the board and members have to work so hard in improving religious education. Obstacles are nothing to not move so much that committee conducted among others by encouraging reward and punishment. Thus the dimension of religious education is achieved, namely to improve education diversity, exemplary and ukhuwah Islamiyah.
\end{abstract}

Keywords: Increasing, Activity, Religion, and Education.

\begin{abstract}
Abstrak
Hasil Penelitian ini menemukan bahwa pengajian bulanan merupakan salah satu program yang menggali aktivitas keberagamaan dalam rangka meningkatkan pendidikan keberagamaan anggota Dharma Wanita Persatuan Institut Agama Islam Negeri (IAIN) Padangsidimpuan. Adapun kendala yang ditemukan yakni penyamaan persepsi tentang penentuan waktu dan jadwal kegiatan karena masing-masing anggota mempunyai kesibukan tersendiri yang juga mendukung aktivitas kegiatan lainnya sebagai istri Pegawai Negeri Sipil dan sebagai Pegawai Negeri Sipil. Kendala lainnya karena sifat heterogen antara pengurus dan anggota sehingga harus kerja keras dalam upaya peningkatan pendidikan keberagamaan. Kendala bukanlah hal untuk tidak beraktivitas maka banyak yang dilakukan pengurus antara lain dengan menggalakkan reward and punishment. Dengan demikian dimensi dari pendidikan keberagamaan tercapai yaitu meningkatkan pendidikan keberagamaan, keteladanan dan ukhuwah islamiyah.
\end{abstract}

Kata Kunci: Peningkatan, Aktivitas, Keberagamaan, dan Pendidikan. 
56 | TAZKIR: Jurnal Penelitian Ilmu-ilmu Sosial dan Keislaman

Vol. 02 No. 2 Desember 2016

\section{PENDAHULUAN}

Dalam rangka mencapai harapan kepada kemajuan wanita, Dharma Wanita Persatuan mengupayakan agar setiap anggota dan keluarganya sejahtera. Mencapai kesejahteraan dipentingkan adanya peningkatan sumber daya insan. Peningkatan yang dapat dilakukan melalui perlindungan dan senantiasa hormat terhadap hak azasinya.

Dharma Wanita Persatuan sebagai wadah untuk berkarya mandiri. Untuk menyahuti itu penting melaksanakan peningkatan pendidikan keberagamaan melalui arisan pada kegiatan rutinitas bulanan. Untuk mencapai tujuan Dharma Wanita Persatuan merupakan kemitraan setiap lembaga pemerintah dalam mewujudkan masyarakat adil dan makmur demi mendambakan kesejahteraan. Dharma Wanita Persatuan mampu membina sumber daya anggotanya sehingga mempunyai budi pekerti yang luhur. Dharma Wanita Persatuan bersatu-padu ikut berjuang untuk mewujudkan masyarakat adil dan makmur sentosa secara merata. Dharma Wanita Persatuan melaksanakan berbagai kegiatan dalam membina istri Pegawai Negeri Sipil dalam rangka meningkatkan mutu pendidikan, aktivitas keberagamaan, ekonomi, sosial dan budaya.

Demikian halnya dengan Dharma Wanita Persatuan Institut Agama Islam Negeri (IAIN) Padangsidimpuan. Dharma Wanita Persatuan Institut Agama Islam Negeri (IAIN) Padangsidimpuan yang selalu beraktivitas sejak Institut Agama Islam Negeri (IAIN) Padangsidimpuan masih cabang dari Institut Agama Islam Negeri (IAIN) Iman Bonjol, kemudian menjadi Sekolah Tinggi Agama Islam Negeri (STAIN) Padangsidimpuan dan sekarang kembali menjadi Dharma Wanita Persatuan Institut Agama Islam Negeri (IAIN) Padangsidimpuan yang di bawah pimpinan Ny. Ibrahim Siregar sudah mulai banyak melakukan aktivitas rutin bulanan dalam rangka peningkatan aktivitas bidang pendidikan keberagamaan, sosial budaya, hubungan masyarakat dan ekonomi.

Berdasarkan pengalaman dan penelitian pendahuluan serta pengamatan penulis bahwa, istri Pegawai Negeri Sipil di Dharma Wanita Persatuan Institut Agama Islam Negeri (IAIN) Padangsidimpuan dalam mengisi kegiatan akktivitas rutin bulanan masih ditemukan ada yang tidak kreatif dan hanya memiliki kemampuan rendah dalam pendidikan keberagamaan. Padahal aktivitas karir ini sangat diperlukan untuk tercapainya perempuan-perempuan yang mempunyai nilai-nilai spritual atau keberagamaan yang saling menghargai 
dan bersilaturrahim. Kegiatan rutin bulanan ini diharapkan mampu meningkatkan aktivitas karir istri Pegawai Negeri Sipil Dharma Wanita Persatuan Institut Agama Islam Negeri (IAIN) Padangsidimpuan mengingat dibutuhkannya istri-istri yang mendukung karir suami. Istri Pegawai Nageri Sipil Dharma Wanita Persatuan Institut Agama Islam Negeri (IAIN) Padangsidimpuan diharapkan mampu memahami peran serta dan tanggung jawab suami di kantor serta menyokong suami dalam hal menjadi abdi bangsa tetap dalam koridor keberagamaan. Pada dasarnya banyak usaha yang dapat dilakukan oleh pengurus dan anggota Dharma Wanita Persatuan Institut Agama Islam Negeri (IAIN) Padangsidimpuan untuk meningkatkan aktivitas pendidikan keberagamaan diantaranya melalui arisan kegiatan rutinitas bulanan di bidang pendidikan dengan cara melaksanakan pendidikan dan pelatihan pengurus dan anggota tentang pentingnya pendidikan. Bidang pendidikan keberagamaan dengan melaksanakan latihan keperempuanan muslimah, pelatihan tata kelola rumah tangga yang islami serta pembinaan pendidikan keberagamaan melalui pemberian materi-materi ibadah dan sekaligus melingkupi bidang kerohanian. Bidang ekonomi dengan peningkatan kesejahteraan anggota melalui pelaksanaan bazar, demo masak setiap rutin dan pendistribusian wira usaha sesama anggota. Bidang sosial budaya dengan pelaksanaan anjangsana bagi anak yatim di sekitar lingkungan perguruan tinggi. ${ }^{1}$

Kegiatan rutinitas bulanan di bidang pendidikan adalah suatu kegiatan dengan melakukan aktivitas yang didalamnya mengkondisikan istri Pegawai Negeri Sipil untuk bekerja sama saling menghargai dan membina jiwa raga di dalam kelompok organisasinya. Kegiatan rutinitas bulanan di bidang pendidikan keberagamaan beranjak dari pemikiran "peningkatkan dimensi-dimensi luhur spritualitas", yang menekankan pada pemberian kesempatan berbuat, berkarya dan berkompetisi yang lebih luas dalam suasana yang kondusif di mana setiap anggota dapat memperoleh pengembangan pengetahuan, sikap, nilai, serta keterampilan-keterampilan sosial yang bermanfaat bagi kehidupan di masyarakat. Kegiatan-kegiatan tersebut dilaksanakan pada saat arisan.

Arisan adalah kelompok kegiatan bulanan yang terdiri dari setiap anggota Dharma Wanita Persatuan sekali dalam satu bulan dengan berbagai

\footnotetext{
${ }^{1}$ Ny. Arbanurrasyid, Wawancara tentang aktivitas karir keberagamaan, Sekretaris Pengurus Dharma Wanita Persatuan Institut Agama Islam Negeri (IAIN) Padangsidimpuan Priode 2013-2017. 12 Maret 2015.
} 
58 | TAZKIR: Jurnal Penelitian Ilmu-ilmu Sosial dan Keislaman

Vol. 02 No. 2 Desember 2016

acara kerohaniaan, keterampilan, pengembangan diri dan kekeluargaan. ${ }^{2}$ Rutinitas Bulanan adalah pertemuan yang dilakukan oleh anggota Dharma Wanita setiap Hari Jum'at Minggu Kedua dan Sabtu setiap Minggi ketiga setiap bulan. Dharma Wanita Persatuan Institut Agama Islam Negeri (IAIN) Padangsidimpuan yaitu nama organisasi yang diikuti beberapa anggota atau kelompok. Jadi arisan pada kegiatan bulanan yang dimaksud oleh peneliti adalah kelompok organisasi yang melakukan kegiatan sekali dalam sebulan yang dihadiri oleh setiap anggota dan pengurus yang memiliki kemampuan berbeda-beda (heterogen) serta latar belakang pengalaman, pengetahuan dan pendidikan.

Guna meningkatkan dan mengembangkan setiap aktivitas karir dalam rangka memerankan persamaan gender di mana pun berada maka anggota Dharma Wanita Persatuan Institut Agama Islam Negeri (IAIN) Padangsidimpuan penting untuk ditelusuri setiap aktivitas karir yang dilakukan yang dalam fokus intinya dalam peningkatan aktivitas pendidikan keberagamaan maka peneliti tertarik untuk menelusuri Peningkatan Aktivitas Pendidikan Keberagamaan Istri Pegawai Negeri Sipil Melalui Arisan pada Kegiatan Rutinitas Bulanan di Dharma Wanita Persatuan Institut Agama Islam Negeri (IAIN) Padangsidimpuan.

Adapun rumusan masalah penelitian ini adalah sebagai berikut:

1. Bagaimanakah peningkatan aktivitas pendidikan keberagamaan istri Pegawai Negeri Sipil melalui arisan pada kegiatan rutinitas bulanan di Dharma Wanita Persatuan Institut Agama Islam Negeri (IAIN) Padangsidimpuan?

2. Apa saja kendala yang dihadapi dalam peningkatan aktivitas Pendidikan Keberagamaan istri Pegawai Negeri Sipil melalui arisan kegiatan rutinitas bulanan di Dharma Wanita Persatuan Institut Agama Islam Negeri (IAIN) Padangsidimpuan?

3. Apa saja dimensi-dimensi keberagamaan istri Pegawai Negeri Sipil yang ditemukan melalui arisan kegiatan rutinitas bulanan di Dharma Wanita Persatuan Institut Agama Islam Negeri (IAIN) Padangsidimpuan bagi kemashlahatan keluarga besar Institut Agama Islam Negeri (IAIN) Padangsidimpuan?

Adapun yang menjadi tujuan penelitian ini sebagai berikut:

\footnotetext{
${ }^{2}$ Tata Aturan dan Tata Tertib Dharma Wanita Persatuan Institut Agama Islam Negeri (IAIN) PadangsidimpuanPriode 2013-2017.
} 
1. Untuk mengetahui peningkatan aktivitas pendidikan keberagamaan istri Pegawai Negeri Sipil melalui arisan pada kegiatan rutinitas bulanan di Dharma Wanita Persatuan Institut Agama Islam Negeri (IAIN) Padangsidimpuan.

2. Untuk mengetahui kendala yang dihadapi dalam peningkatan aktivitas pendidikan keberagamaan istri Pegawai Negeri Sipil melalui arisan kegiatan rutinitas bulanan di Dharma Wanita Persatuan Institut Agama Islam Negeri (IAIN) Padangsidimpuan.

3. Untuk mengetahui dimensi-dimensi keberagamaan istri Pegawai Negeri Sipil melalui arisan kegiatan rutinitas bulanan di Dharma Wanita Persatuan Institut Agama Islam Negeri (IAIN) Padangsidimpuan bagi kemashlahatan keluarga besar Institut Agama Islam Negeri (IAIN) Padangsidimpuan.

\section{TINJAUAN PUSTAKA}

\section{Pengertian Peningkatan Aktivitas Pendidikan Keberagamaan}

Kata "beragama" itu sendiri memang bisa mengandung berbagai makna dan dimensi. Keberagamaan berkaitan dengan pengetahuan tentang berbagai konsep keagamaan, keyakinan pada doktrin-doktrin, ketaatan pemeluk menjalankan ritual, pengalaman mistik atau keterlibatan pada berbagai aktivitas keagamaan.

Berkaitan dengan kata "beragama" itu, C.Y. Glock \& R. Stark dalam American Piety: The Nature of Religious Commitment menyebutkan lima dimensi keberagaamaan; belief dimension, ritual dimension, consequential dimension, experiential dimension dan knowledge dimension. ${ }^{3}$

Menurut Jamaluddin Ancok ${ }^{4}$ lima dimensi keberagamaan rumusan Glock \& Stark itu melihat keberagamaan tidak hanya dari dimensi ritual semata tetapi juga pada dimensi-dimensi lain. Ancok menilai, meskipun tidak sepenuhnya sama, lima dimensi keberagamaan rumusan Glock \& Stark itu bisa disejajarkan dengan konsep Islam. Dimensi ideologis bisa disejajarkan dengan akidah, dimensi ritual bisa disejajarkan dengan syari'ah, khususnya ibadah, dan dimensi konsekuensial bisa disejajarkan dengan akhlak. Akidah, syari'ah dan akhlak adalah inti dari ajaran Islam. Dimensi intelektual mempunyai peran yang cukup penting pula karena pelaksanaan dimensi-dimensi lain sangat membutuhkan

${ }^{3}$ C.Y. Glock \& R. Stark dalam American Piety: The Nature of Religious Commitment (New York: Rineho1t, 968), p.33.

${ }^{4}$ Jamaluddin Ancok \& Fuad Nashori, Psikologi Islami (Yogyakarta: Pustaka Pelajar, 2005), h. 44. 
60 | TAZKIR: Jurnal Penelitian Ilmu-ilmu Sosial dan Keislaman

Vol. 02 No. 2 Desember 2016

pengetahuan terlebih dahulu. Sedangkan dimensi eksperiensial dapat disejajarkan dengan dimensi tasawuf atau dimensi mistik.

Dalam perspektif Islam, keberagamaan harus bersifat menyeluruh sebagaimana diungkap dalam Al-Qur'an 2: 208, yang artinya: Hai orang-orang yang beriman, masuklah kamu ke dalam Islam keseluruhan, dan janganlah kamu turut langkah-langkah syaitan. Sesungguhnya syaitan itu musuh yang nyata bagimu.

Bahwa orang-orang yang beriman harus masuk ke dalam Islam secara menyeluruh (kaffah). Oleh karena itu seorang muslim harus mempunyai keyakinan terhadapakidah Islam, mempunyai komitmen dan kepatuhan terhadap syari'ah, mempunyai akhlak yang baik, ilmu yang cukup dan jiwa yang sufistik.

\section{Dimensi Keberagamaan}

Yang pertama adalah dimensi intelektual; setiap agama memiliki sejumlah informasi khusus yang harus diketahui oleh para pemeluknya. Dalam Islam, misalnya ada informasi tentang berbagai aspek seperti pengetahuan tentang al-Qur'an dengan segala bacaan, isi dan kandungan maknanya, alHadits, berbagai praktek ritual atau ibadah dan muamalah, konsep keimanan, berbagai konsep dan bentuk akhlak, tasawuf, sejarah dan peradaban masyarakat Islam. Selanjutnya dimensi ideologis; dimensi ini merupakan bagian dari keberagamaan yang berkaitan dengan apa yang harus dipercayai dan menjadi sistem keyakinan (creed). Doktrin mengenai kepercayaan atau keyakinan adalah yang paling dasar yang bisa membedakan agama satu dengan lainnya. Dalam Islam, keyakinan-keyakinan ini tertuang dalam dimensi akidah. Akidah Islam dalam istilah al-Qur'an adalah iman. Iman tidak hanya berarti percaya melainkan keyakinan yang mendorong munculnya ucapan dan perbuatanperbuatan sesuai dengan keyakinan. Iman dalam Islam terdapat dalam rukun iman yang berjumlah enam.

Dimensi eksperiensial adalah dimensi selanjutnya yang merupakan bagian dari keberagamaan yang berkaitan dengan perasaan keagamaan seseorang. Psikologi agama menyebutnya sebagai pengalaman keagamaan (religious experience) yaitu unsur perasaan dalam kesadaran agama yang membawa pada suatu keyakinan. ${ }^{5}$ Pengalaman keagamaan ini bisa terjadi dari yang paling sederhana seperti merasakan kekhusukan pada waktu shalat dan

${ }^{5}$ Zakiah Darajat, Islam dan Kesehatan Mental (Jakarta: Gunung Agung, 1996), h. 67. 
ketenangan setelah menjalankannya, atau merasakan nikmat dan bahagia ketika memasuki bulan Ramadlan. Berikutnya adalah dimensi ritual, yang merupakan bagian dari keberagamaan yang berkaitan dengan perilaku yang disebut ritual keagamaan seperti pemujaan, ketaatan dan hal-hal lain yang dilakukan untuk menunjukkan komitmen terhadap agama yang dianutnya. Perilaku di sini bukan perilaku dalam makna umum, melainkan menunjuk kepada perilaku-perilaku khusus yang ditetapkan oleh agama seperti tata cara beribadah dan ritus-ritus khusus pada hari-hari suci atau hari-hari besar agama. Dimensi ini sejajar dengan ibadah. Ibadah merupakan penghambaan manusia kepada Allah sebagai pelaksanaan tugas hidup selaku makhluk Allah. Ibadah yang berkaitan dengan ritual adalah ibadah khusus atau ibadah mahdhah, yaitu ibadah yang bersifat khusus dan langsung kepada Allah dengan tatacara, syarat serta rukun yang telah ditetapkan dalam Al-Qur'an serta penjelasan dalam hadits nabi. Ibadah yang termasuk dalam jenis ini adalah shalat, zakat, puasa dan haji.

Dimensi konsekuensial merupakan dimensi selanjutnya yang menunjuk pada konsekuensi-konsekuensi yang ditimbulkan oleh ajaran agama dalam perilaku umum yang tidak secara langsung dan khusus ditetapkan oleh agama seperti dalam dimensi ritualis. Walaupun begitu, sebenarnya banyak sekali ditemukan ajaran Islam yang mendorong kepada umatnya untuk berperilaku yang baik seperti ajaran untuk menghormati tetangga, menghormat tamu, toleran, inklusif, berbuat adil, membela kebenaran, berbuat baik kepada fakir miskin dan anak yatim, jujur dalam bekerja, dan sebagainya. Perilaku umum ini masuk dalam wilayah hubungan manusia (hablum minannas) yang mestinya harus tidak bisa dipisahkan dari hubungan kepada Allah (hablum minallah). Iman, menurutnya bisa bertambah dan berkurang oleh tindakan-tindakan yang dilakukan seseorang. Konsekuensi tindakan ini, dalam hal-hal tertentu, terkadang lebih berat daripada keyakinan dan ritual.

Tujuan ibadah atau ritual dalam Islam bukan hanya untuk menyembah Allah semata, melainkan untuk mendekatkan diri kepada Allah agar manusia selalu teringat kepada hal-hal yang baik dan suci sehingga mendorongnya untuk berperilaku yang luhur, baik kepada sesama manusia maupun kepada lingkungan alam sekitar.

\section{Implikasi dalam Pendidikan Keberagamaan}

Melihat lima dimensi keberagamaan di atas, maka tugas pendidikan keberagamaan membentuk insan yang "beragama" akan meliputi wilayah yang 
62 | TAZKIR: Jurnal Penelitian Ilmu-ilmu Sosial dan Keislaman

Vol.02 No. 2 Desember 2016

cukup luas, paling tidak meliputi lima dimensi di atas. Masing-masing dimensi harus mendapatkan pengelolaan dan perlakuan berbeda, baik dari segi tujuan, materi, pengalaman belajar, metode, media, perencanaan maupun teknik pengukuran dan penilaiannya.

Selain itu, pendidikan keberagamaan yang ada di setiap lingkungan juga mesti memperluas kerjasama dengan pihak-pihak luar lingkungan lainnya seperti keluarga (orang tua) dan masyarakat, karena keberagamaan tidak mungkin diukur hanya pada saat berada di lingkungan tempat kita berada. Ekspresi pada kehidupan yang sebenarnya, yaitu ketika berada di mana pun saja berada sehingga cukup representatif untuk melihat tingkat keberagamaan.

Melihat lima dimensi keberagamaan berikut implikasinya dalam aktivitas pendidikan keberagamaan, maka implementasi pendidikan keberagamaan membutuhkan perencanaan, persiapan dan skill yang matang serta dukungan yang cukup dari sekolah, orang tua serta masyarakat. Penerapan Competency Based Curriculum, merupakan acuan awal yang cukup mendukung untuk mengimplementasikan aktivitas pendidikan keberagamaan yang kaffah yang bisa menyentuh berbagai dimensi keberagamaan.

\section{Istri Pegawai Negeri Sipil}

Di dalam suatu organisasi yang ada di Indonesia tidak terkecuali di dalam organisasi Dharma Wanita Persatuan memiliki suatu anggota di dalamnya yang masing-masing memiliki wewenang, anggota dari organisasi tersebut terdiri dari:

1. Istri pegawai negeri sipil (PNS)

2. Istri pejabat negara bidang pemerintahan

3. Istri pensiunan dan janda PNS

4. Istri pegawai badan usaha milik negara (BUMN) dan badan usaha milik daerah (BUMD) yang belum berstatus persero

5. Istri pensiunan dan janda pegawai BUMN dan BUMD yang belum berstatus persero

6. Istri kepala perwakilan Republik Indonesia di luar negeri

7. Istri anggota TNI, purnawirawan ataupun polisi

8. Pensiunan PNS wanita

9. Istri perangkat pemerintahan desa. ${ }^{6}$

${ }^{6}$ http://id.wikipedia.org/wiki/Dharma_Wanita 14 April 2015 


\section{Dharma Wanita Persatuan}

Dharma Wanita adalah sebuah organisasi yang beranggotakan istri Pegawai Negeri Sipil (PNS). ${ }^{7}$ Organisasi yang beranggotakan istri pegawai negeri sipil ini diatur tugas dan kewajibannya dalam anggaran dasar dan anggaran rumah tangga Dharma Wanita Persatuan. Masing-masing pengurus dan anggota mempunyai peran serta dalam mengembangkan dan membesarkan organisasi Dharma Wanita Persatuan.

Dharma Wanita Persatuan ditetapkan pada tanggal 7 Desember 1999 pada sebuah rapat nasional. ${ }^{8}$ Penetapan ini karena layak penting dalam membina aktivitas karir istri Pegawai Negeri Sipil. Dalam rangka menampung aspirasi serta kreativitas istri Pegawai Negeri Sipil maka dipandang perlu dibentuk organisasi Dharma Wanita Persatuan sebagai wadah dalam membina karya dengan mandiri. Dharma Wanita Persatuan adalah organisasi kemasyarakatan yang menghimpun dan membina istri Pegawai Negeri Sipil RI dengan kegiatan yang bergerak dalam bidang pendidikan, ekonomi dan sosial budaya serta tidak terkait dengan kekuatan politik manapun, tetapi hak berpolitik anggota tetap dihormati.

Secara garis besar, tujuan organisasi Dharma Wanita adalah mewujudkan kesejahteraan anggota dan keluarganya melalui peningkatan kualitas sumber daya anggota untuk mendukung tercapainya tujuan nasional berdasarkan Pancasila dan Undang-undang Dasar 1945. Kegiatan yang dilaksanakan oleh Dharma Wanita Persatuan diarahkan untuk:

1. Mengutamakan kegiatan untuk meningkatkan kualitas sumber daya manusia dari pengurus dan anggota

2. memilih kegiatan sesuai dengan kebutuhan, kemampuan, kesempatan organisasi.

3. dalam melaksanakan kegiatan mendahulukan yang penting sesuai dengan skala prioritas.

4. mengutamakan kualitas penanganannya daripada kualitas yang ditangani, serta diupayakan secara tuntas.

5. menjaga citra yang baik sebagai istri pendamping aparat pemerintah di tengah masyarakat yang dinamis. ${ }^{9}$

${ }^{7}$ http://id.wikipedia.org/wiki/Dharma_Wanita diakses 14 April 2015

${ }^{8}$ http://id.wikipedia.org/wiki/Dharma_Wanita 14 April 2015 Dasar 1945.

Tujuan Nasional Dharma Wanita persatuan Pusat berdasarkan Pancasila dan Undang-undang 
64 | TAZKIR: Jurnal Penelitian Ilmu-ilmu Sosial dan Keislaman

Vol.02 No. 2 Desember 2016

Dharma Wanita Persatuan juga berharap agar aktivitas Dharma Wanita Persatuan perlu terus dikembangkan ke arah pemberdayaan organisasi dan mengutamakan pembinaan sumber daya manusia (SDM). Selain itu, seluruh jajaran pengurus harus mampu mengayomi anggotanya serta mampu bekerjasama dengan mitra pengurus Korpri dan lainya. Dharma Wanita juga memiliki tugas dan fungsi pokok yang telah dibuat oleh kelompoknya, tugas tersebut berisi: membina anggota dalam memperkukuh persatuan dan kesatuan, meningkatkan kemampuan dan pengetahuan, menjalin hubungan kerjasama dengan berbagai pihak, serta meningkatkan kepedulian sosial. Tugas dari Dharma Wanita yang kedua adalah melakukan pembinaan mental dan spritual anggota agar menjadi manusia yang bertawakkal kepada Tuhan Yang Maha Esa, berkepribadian, serta berbudi pekerti luhur. Sedangkan fungsinya adalah sebagai wadah untuk melakukan pembinaan, perencanaan, pelaksanaan dan pengendalian kegiatan yang berkaitan dengan pelaksanaan tugas pokok organisasi.

Sedangkan tugas dan wewenang pengurus sendiri adalah :

Menetapkan kebijaksanaan tekhnis organisasi berdasarkan hasil musyawarah nasional, anggaran dasar, anggaran rumah tangga dan juga kebijaksaan organisasi satu tingkat diatasnya;

Mengesahkan organisasi, pengurus dan atau ketua satu tingkat dibawahnya;

Melaksanakan pembinaan organisasi pada unsur pelaksana di lingkunganya;

Memantau dan mengevaluasi pelaksanaan dan kebijaksanaan yang dilakukan oleh unsur pelaksana di lingkunganya;

Melaksanakan program dan kegiatan yang sesuai dengan situasi dan kondisi yang sedang terjadi;

Melaporkan pelaksanaan tugasnya kepada organisasi satu tingkat diatasnya. ${ }^{10}$

Organisasi yang beranggotakan kaum perempuan ini memiliki visi "Menjadi organisasi istri Pegawai Negeri Sipil yang kukuh, bersatu, dan mandiri", sedangkan misinya adalah "Mensejahterakan anggota melalui bidang pendidikan, bidang ekonomi, dan bisang sosial budaya".

Di dalam organisasi Dharma Wanita Persatuan yang ada di Indonesia sangatlah banyak dan di antara satu dengan yang lain memiliki program yang berbeda-beda. Hal ini juga dilakukan oleh Dharma Wanita Persatuan Institut Agama Islam Negeri (IAIN) Padangsidimpuan yang menghasilkan beberapa program kegiatan yang dilaksanakan antara lain adalah :

\footnotetext{
${ }^{10}$ http://firdaaprilianto.blogspot.com/2011/12/organisasi-perempuan-dharma-wanita.html
} 
1. Bidang pendidikan

Di bidang pendidikan, Dharma Wanita telah bergerak dalam dua kegiatan, yakni pendidikan formal dan non formal. Pendidikan formal, Sebagai wujud kepedulian terhadap pendidikan, Dharma Wanita telah meretas pengelola pendirian Pendidikan Anak Usia Dini (PAUD) yaitu sebagai wadah bagi perempuan karir untuk menitipkan anak-anak mereka dan memberikan pendidikan pada saat bekerja sebagai Pegawai Negeri Sipil. Upaya lain dalam rangka peningkatan mutu pendidikan seperti bekerjasama dengan pihak-pihak yang bersedia membantu, diantaranya adalah penghijauan tanaman sekolah untuk aksi hijau berseri sehingga ada pendidikan tentang penanaman kembali lahan-lahan lingkungan kampus yang gersang, pengadaan tenaga tata usaha yang kreatif dari jurusan Tarbiyah, Syari'ah, Dakwah, Ekonomi dan Bisnis dan lain-lain. Di samping pendidikan formal, Dharma Wanita juga menyelenggarakan pendidikan non formal yang bertujuan untuk meningkatkan pengetahuan dan wawasan para anggota Dharma Wanita Persatuan di Institut Agama Islam Negeri (IAIN) Padangsidimpuan. Kegiatan yang dilakukan diantaranya adalah ceramah seperti ceramah etika dalam berbusana muslimah, materi tentang ibadah thaharoh, shalat jenazah dan ibadah Fiqh lainnya. Bidang sosial budaya mengadakan kunjungan kerja atau yang lainya.

2. Bidang Pendidikan Keberagamaan,

Sebagai bidang yang memberikan nilai ibadah duniawi dan akhirat Dharma Wanita Persatuan menyelenggarakan kegiatan tentang pembinaan menjadi istri shalehah dan maratun shalehah. Melakukan pembinaan dalam tata cara pelaksanaan shalat atau ibadah lainnya yang mendukung keutuhan rumah tangga Pegawai Negeri Sipil serta melakukan kegiatan pembinaan pendidikan keberagamaan yang sifatnya tentatif seperti silaturrahim, ukhuwah islamiah dan penanaman nilai-nilai akhlakul karimah.

3. Bidang Ekonomi,

Bidang ekonomi merupakan bidang yang meliputi usaha untuk meningkatkan kemampuan menghimpun dana untuk menggerakkan roda organisasi maupun untuk meningkatkan kesejahteraan para pengurus anggota. Dan hasil dari kerjasama yang telah dilakukan dalam bidang ekonomi sendiri adalah dibuatnya sebuah kantin dan kegiatan lain dalam bidang ekonomi adalah menghimpun tabungan pengurus, 
66 | TAZKIR: Jurnal Penelitian Ilmu-ilmu Sosial dan Keislaman

Vol.02 No. 2 Desember 2016

simpan pinjam, penjualan PIN Dharma Wanita, pakaian Dharma Wanita dan busana muslimah dan lain-lain. Semua hal tersebut merupakan suatu program dari organisasi Dharma Wanita Persatuan

4. Bidang Sosial Budaya,

Bidang sosial budaya merupakan suatu bidang yang meliputi usaha pemahaman penghayatan, serta pengalaman norma dan nilai yang mengakar dalam kehidupan di Indonesia. Sebagai wujud kepedulian pada lingkungan sekitar, telah dilakukan kegiatan ke pantai asuhan dengan menyerahkan bantuan sesuai kemampuan mengunjungi anggota Dharma Wanita Persatuan yang sakit, berkabung atau mengalami musibah, berpartisipasi aktif dalam kegiatan sosial dan memberikan sumbangan dana dalam kegiatan bakti sosial dan santunan anak yatim.

\section{METODOLOGI PENELITIAN}

Pendekatan yang digunakan dalam penelitian ini disifatkan sebagai pendekatan studi kasus (case-study approach). Implementasi dari penelitian yang menggunakan pendekatan studi kasus yang dilakukan di Institut Agama Islam Negeri (IAIN) Padangsidimpuanini menggunakan desain yang dikemukakan oleh Bogdan dan Biklen yang disajikan dalam bentuk funnel (cerobong). Pendekatan dalam penelitian ini bersifat kualitatif, maka instrumen penelitian adalah peneliti sendiri (TPF).

\section{HASIL PENELITIAN DAN PEMBAHASAN}

Dari penelitian ini maka ditemukan bahwa:

1. Peningkatan aktivitas pendidikan keberagamaan istri Pegawai Negeri Sipil melalui arisan pada kegiatan rutinitas bulanan di Dharma Wanita Persatuan Institut Agama Islam Negeri (IAIN) Padangsidimpuan dilakuan dengan berbagai kegiatan dan bidang, antara lain: bidang pendidikan ini memiliki banyak program antara lain kegiatan rutinitas pengajian bulanan yang digelar setiap Sabtu Minggu ketiga setiap bulannya. Pengajian bulanan merupakan salah satu program yang menggali aktivitas keberagamaan dalam rangka meningkatkan pendidikan keberagamaan anggota Dharma Wanita Persatuan Institut Agama Islam Negeri (IAIN) Padangsidimpuan. Pendidikan keberagamaan ini juga melingkupi kegiatan rutin Dharma Wanita Persatuan Institut Agama Islam Negeri (IAIN) Padangsidimpuan. Pelaksanaan pendidikan keberagamaan dilakukan sesuai dengan jadwal 
arisan Dharma Wanita Persatuan Institut Agama Islam Negeri (IAIN) Padangsidimpuan. Dalam rangka mendalami dan melengkapi pelaksanaan aktivitas pendidikan keberagamaan dilaksanakan kembali arisan keluarga besar Dharma Wanita Persatuan Institut Agama Islam Negeri (IAIN) Padangsidimpuan pada minggu ketiga hari Sabtu di setiap rumah pengurus dan anggota secara bergiliran.

2. Kendala yang dihadapi dalam peningkatan aktivitas pendidikan keberagamaan istri Pegawai Negeri Sipil melalui arisan kegiatan rutinitas bulanan di Dharma Wanita Persatuan Institut Agama Islam Negeri (IAIN) Padangsidimpuan adalah:

a. Kendala tentang kehadiran anggota, di samping penyebaran undangan yang terjadwal juga dapat dilakukan dengan pemberitahuan melalui sms, serta dengan memberkan lucky draw.

b. Tanggung jawab anggota, seperti memberikan kepercayaan kepada setiap anggota untuk terlibat langsung mensukseskan kegiatan dengan membagi tugas dan tanggung jawab artinya dengan mengakui bersama bahwa kerja yang bagus adalah untuk kemashlahatan bersama juga.

c. Jadwal yang berobah-obah dan tempat yang tidak permanen sesungguhnya merupakan lanhkah awal untuk mengenal semua lingkungan kampus Institut Agama Islam Negeri (IAIN) Padangsidimpuan. Berbeda-bedanya tempat berarti ada kesempatan bagi setap anggota dan pengurus mengetahui tata letak lingkungan kampus yang sesungguhnya dapat dimanfaatkan untuk pembinaan anggota.

d. Materi yang tidak berkesinambungan, kendala ini dapat diatasi dengan membuat kerja sama dengan penceramah agar saling isi mengisi dan membuat kajian ilmu yang sama dalam bentuk tulisan.

e. Aktivitas yang padat, diatasi dengan menyesuaikan kegiatan dengan aktivitas yang dialami anggota dan pengurus sehingga anggota dan pengurus tidak mencari kegiatan di luar tetapi telah terpenuhi di Dharma Wanita Persatuan Institut Agama Islam Negeri (IAIN) Padangsidimpuan.

f. Kebutuhan anggota yang heterogen juga dapat diatasi dengan menyamakan kebutuhan bersama dan membuatnya secara bergiliran, seperti saat ini kebutuhan aktivitas pendidikan keberagamaan bidang 
68 | TAZKIR: Jurnal Penelitian Ilmu-ilmu Sosial dan Keislaman

Vol.02 No. 2 Desember 2016

ibadah, selanjutnya syariah dan akhlak. Sehingga anggota merasakan terpenuhi kebutuhannya.

g. Visi dan Persepsi yang beragam pada dasarnya merupakan kekayaan ilmu pengetahuan dan wawasan, untuk ini cara penaggunlangannya dapat dilakukan dengan membuat wadah menampung visi dan persepsi yang berbeda tersebut untuk disatukan dan diberdayakan.

3. Dimensi-dimensi keberagamaan istri Pegawai Negeri Sipil melalui arisan kegiatan rutinitas bulanan di Dharma Wanita Persatuan Institut Agama Islam Negeri (IAIN) Padangsidimpuan adalah:

a. Nilai Intelektual

b. Nilai Idiologis

c. Nilai Eksperiensial

d. Nilai Ritual

e. Nilai Konsekuensial

f. Nilai Pendidikan Keteladanan Akhlak

g. Nilai Pendidikan Keteladanan Kepemimpinan

h. Nilai Pendidikan Keteladanan Jati Diri

i. Nilai Pendidikan dan Silaturrahim Anggota

j. Nilai Pendidikan dan Silaturrahim Pengurus.

\section{PENUTUP}

Dharma Wanita sebagai organisasi dalam membina aktivitas karir istri Pegawai Negeri Sipil mampu menampung aspirasi serta kreativitas istri Pegawai Negeri Sipil. Organisasi Dharma Wanita Persatuan sebagai wadah dalam membina karya dengan mandiri mampu mewujudkan kesejahteraan anggota dan keluarganya melalui peningkatan kualitas sumber daya anggota untuk mendukung tercapainya tujuan nasional.

Dharma Wanita Persatuan juga berharap agar aktivitas Dharma Wanita Persatuan perlu terus dikembangkan ke arah pemberdayaan organisasi dan mengutamakan pembinaan sumber daya manusia (SDM). Di Institut Agama Islam Negeri (IAIN) Padangsidimpuan organisasi Dharma Wanita Persatuan mempunyai banyak aktivitas keberagamaan yang dilaksanakan secara rutin dalam setiap bulannya. Organisasi Dharma Wanita Persatuan Institut Agama Islam Negeri (IAIN) Padangsidimpuan bergerak dalam melaksanakan pembinaan organisasi dan melaksanakan program dan kegiatan yang sesuai dengan situasi dan kondisi dan kebutuhan anggotanya. 


\section{DAFTAR RUJUKAN}

Anggaran Dasar Dharma Wanita Persatuan Pusat, Jakarta 9 Desember 2004.

Anggaran Dasar Dharma Wanita Persatuan Pusat, Jakarta 9 Desember 2004 Pasal 1.

Bogdan, R.C. \& Biklen, S.K. Qualitative Research For Education: An Introduction to Theory and Method, Boston: Allyn and Bacon, Inc, 1982.

Burgess, Issues and Educatiobal Reseach: Qualitative Methode, London and Philadelphia, The Palmer Press, 1985.

Caprio, Di. Metode dan Teknik Penelitian Masyarakat, Jakarta: Gramedia.1974.

Danandjaja, James. Mengumpulkan Folklore Bali Aga di Trunyan, Jakarta:Gramedia,1994.

Daradjat, Zakiah. Islam dan Kesehatan Mental, Jakarta: Gunung Agung, 1996.

Donald, Ary. Intoduction to Reseach in Education, New York: Holt Rinehart and Winston, 1982.

Glock, C.Y. \& R. Stark dalam American Piety: The Nature of Religious Commitment, New York: Rineho1t, 968.

Goetz dan Le Compte, Etnogrhapy and Qualitatitive Design in Educational Reseach, Tokyo: Academic Press Inc, 1981.

http:/firdaaprilianto.blogspot.com/2011/12/organisasi-perempuan-dharmawanita.html.

http://id.wikipedia.org/wiki/Dharma_Wanita 14 April 2015.

http://id.wikipedia.org/wiki/Dharma_Wanita 14 April 2015.

http://id.wikipedia.org/wiki/Dharma_Wanita diakses 14 April 2015.

Jamaluddin Ancok \& Fuad Nashori, Psikologi Islami, Yogyakarta: Pustaka Pelajar, 2005.

Lofland, Jhon.\& Lyn H Lofland, Analizying Social Settings Guide to Qualitative Observation and Analysis, Belmont Cal: Wadworth Publishing Company,1987. 
70 | TAZKIR: Jurnal Penelitian Ilmu-ilmu Sosial dan Keislaman

Vol.02 No. 2 Desember 2016

Mantja, Supervisi pengajaran: Kasus pembinaan profesional guru sekolah dasar negeri kelompok budaya etnik Madura di Kraton. Disertasi tak dipublikasikan. IKIP Malang. 1989.

Miles \& Huberman, Qualitative Data Analysis a SourcesBook of NewMethods, Beverly Hills, CA: Sage Publ, 1984.

Moleong, Lexy J. Metodologi Penelitian Kualitatif, Bandung: PT. Remaja Rosdakarya, 2000.

Nasution, S. Metode Penelitian Naturalistik Kualitatif, Bandung: Tarsito, 1992.

Pitomo, Profil Pembelajaran Keterampilan Luar Pertanian Rumah Tangga Berpenghasilan Rendah di desa Dayu Kediri. Tesis tidak dipublikasikan, Malang: FPS IKIP Malang. 1990.

Q.S. Al-Baqorah:208.

Qwens, Organization Behavior in Education, New Jersey: Prentice Hall Inc, 1987.

Simanungkalit, N. Hymne Dharma Wanita Persatuan.

Soegiyanto, Desain dalam penelitian kualitatif. Makalah Penataran Penelitian Dosen IKIP Surabaya, Surabaya: Puslit. IKIP,1989

Soetopo, Konsep-Konsep Dasar dalam Penelitian Kualitatif. Makalah Seminar Nasional Penelitian Dosen FKIP/FIS UNS, Surakarta: 26-27 Agustus.1988.

Surachman, Winarno. Dasar-Dasar Teknik Reseach Pengantar Metodologi Ilmiah, Bandung: Tarsito, 1982.

Tata Aturan dan Tata Tertib Dharma Wanita Persatuan Institut Agama Islam Negeri (IAIN) Padangsidimpuan Priode 2013-2017.

Tujuan Nasional Dharma Wanita persatuan Pusat berdasarkan Pancasila dan Undang-undang Dasar 1945.

Vonne S, Lincoln Y. dan Guba Egon G, Naturalistic Inquiry, Baverly Hills: Sage Publication, Inc, 1986.

Vredenbregt, Pengantar Metodologi Untuk Ilmu-Ilmu Empiris, Jakarta: Gramedia, 1987.

William, Naturalistic Inquiry Materials, Bandung: Fakultas Pascasarjana IKIP, 1988. 